\begin{tabular}{|c|c|}
\hline 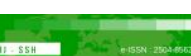 & Malaysian Journal of Social Sciences and Humanities (MJSSH) \\
\hline Malaysian Journal of & Volume 5, Issue 11, November 2020 \\
\hline (MJ-SSH) & e-ISSN : 2504-8562 \\
\hline & $\begin{array}{l}\text { Journal home page: } \\
\text { www.msocialsciences.com }\end{array}$ \\
\hline
\end{tabular}

\title{
Mengatasi Kebimbangan Semasa Pandemik COVID-19 dengan Pendekatan Teori Rational Emotive Behaviour Theraphy (REBT)
}

\author{
Norhazirah Mustaffa ${ }^{1}$ \\ ${ }^{1}$ Fakulti Pengajian Kontemporari Islam, Kolej Profesional Baitulmal Kuala Lumpur \\ Correspondence: Norhazirah Mustaffa (norhazirahmustaffa@gmail.com)
}

\begin{abstract}
Abstrak
COVID-19 yang melanda dunia bermula Disember 2019 telah meningkatkan kadar kebimbangan masyarakat seluruh dunia dan menyebabkan peningkatan isu-isu kesihatan mental antaranya kebimbangan, kemurungan, dan lain-lain. Ini kerana penularan wabak ini telah memberi impak yang besar kepada manusia terutamanya isu kesihatan, ekonomi, pendidikan dan aktiviti sosial. Teori Rational Emotive Behaviour Theraphy (REBT) adalah salah satu teori yang digunakan dalam sesi kaunseling atau terapi namun penerokaan tentang penggunaan teori ini dalam mengatasi kebimbangan semasa pandemik masih kurang. Objektif kajian ini adalah untuk membincangkan penggunaan terapi ini bagi mengatasi kebimbangan yang dialami klien dalam situasi pandemik COVID-19 seterusnya mengaplikasikannya dengan teknik ABCDE. Kajian ini merupakan kajian dokumentasi yang menganalisis kajian- kajian lepas tentang peningkatan kebimbangan semasa COVID-19 serta penggunaan teori Rational Emotive Behaviour Theraphy (REBT) dalam isu-isu kebimbangan yang lain. Kajian ini mendapati terapi ini mampu membantu mengatasi kebimbangan semasa musim COVID-19.
\end{abstract}

Kata kunci: Teori REBT, COVID-19, kebimbangan

\section{Overcoming Anxiety during COVID-19 Pandemic with the Approach of Rational Emotive Behaviour Theraphy (REBT) Theory}

\begin{abstract}
COVID-19 which hit the world starting December 2019 has increased the rate of public concern around the world and caused an increase in mental health issues including anxiety, depression, and others. This is because the spread of this pandemic has had a huge impact on human beings, especially economic issues, health and social activities. The Rational Emotive Behavior Therapy (REBT) theory is one of the theories used in counseling or therapy sessions but the exploration of using this theory in overcoming anxiety in the pandemic season is still lacking. The objective of this study is to discuss the use of this therapy to overcome anxiety that is experienced by the client during the COVID-19 season and then apply it with $\mathrm{ABCDE}$ technique. This study is a documentation study that analyzes past studies on currently escalating cases of anxiety during COVID-19 as well as the using of Rational Emotive Behavior Therapy (REBT) theory in other anxiety issues. This study found that this therapy is able to overcome anxiety during the COVID-19.
\end{abstract}


Keywords: REBT therapy, Covid 19, anxiety

\section{Pengenalan}

Novel Coronavirus 2019 atau COVID-19 pertama kali mula dikesan di Wuhan, iaitu di wilayah Hubei, China pada Disember 2019 dimana akhirnya Pertubuhan Kesihatan Sedunia (WHO) telah mengisytiharkan ia sebagai global pandemik yang mengancam kesihatan oang ramai dari sudut fizikal dan juga psikologi (Buheji et al. 2020). Ia telah menjadi stressor kerana memberi kesan kepada kehidupan manusia dalam pelbagai aspek, iaitu ekonomi, aktiviti sosial, kesihatan, pendidikan, politik dan budaya malahan masih tiada lagi vaksin yang boleh mengatasi wabak ini lagi.

Ekoran itu muncullah peningkatan isu-isu kesihatan mental dan gangguan psikologi seperti kebimbangan dan cemas dalam kalangan masyarakat kerana terkesan dengan impak negatif yang dibawa oleh pandemik ini. Antaranya, seluruh dunia menyaksikan ribuan jumlah angka yang terkorban setiap hari akibat wabak ini, rutin sosial yang mula berubah dan aktiviti sosial yang terganggu seperti majlis keramaian, aktiviti ibadah malah yang lebih kritikal sumber pendapatan masyarakat terjejas kerana tidak dapat lagi menjalankan aktiviti perniagaan seperti biasa (Jarnawi, 2020). Kajian lepas menunjukkan meningkatnya kadar kebimbangan di kalangan penduduk dunia antaranya kajian yang dilakukan oleh Wang et al. (2020) terhadap 1210 0rang responden daripada 194 bandar di China mendapati 53.8\% responden terkesan secara psikologi dengan penyebaran virus tersebut dimana sejumlah $28.8 \%$ responden melaporkan mengalami simptom kebimbangan daripada sederhana kepada teruk. Dapatan ini juga disokong oleh kajian Roy et al. (2020) di India dan Çalık (2020) di Turki. Selain itu, Kajian Choi et. al (2020) terhadap 500 orang responden di bandar Hong Kong juga mendapati $25.4 \%$ responden mengalami kesihatan mental yang menurun sejak pandemik tersebut melanda.

Sebagaimana krisis yang dialami oleh masyarakat seluruh dunia, negara kita Malaysia juga turut mengalami peningkatan dalam isu-isu kesihatan mental antaranya kebimbangan. Sebuah kajian dijalankan oleh Sundarasen et al. (2020) terhadap 983 orang responden dalam kalangan pelajar di Malaysia mendapati sebanyak $20.4 \%, 6.6 \%$ dan $2.8 \%$ pelajar mengalami kebimbangan di tahap minima kepada sederhana, sederhana teruk dan sangat teruk semasa dalam tempoh Perintah Kawalan Pergerakan (PKP). Kajian ini juga disokong oleh dapatan kajian Baloran et al. (2020) dimana majoriti pelajar mengalami kebimbangan akibat wabak ini.

Menurut Chhabra (2020) terdapat pelbagai intervensi yang boleh dilakukan dalam mengatasi isu kesihatan mental dalam pandemik COVID-19 seperti sokongan psikososial, pendidikan, farmakologi, terapi CBT (Cognitive Behaviour Theraphy) dan juga terapi- terapi yang lain. Walaupun terdapat pelbagai kajian yang mengkaji tentang impak COVID-19 terhadap kesihatan mental namun perbincangan mengenai penggunaan terapi khususnya REBT dalam menangani kebimbangan semasa musim pandemik COVID-19 masih terhad. Justeru itu, kajian ini akan membincangkan isu- isu yang menyebabkan peningkatan kebimbangan yang dialami semasa pandemik COVID-19 serta bagaimana REBT mampu diaplikasikan dalam mengatasi kebimbangan yang dialami menggunakan teknik ABCDE.

Dalam kajian ini, pada awalnya pengkaji membincangkan tentang krisis dan impak COVID- 19 terhadap pelbagai sektor dalam masyarakat, seterusnya menghuraikan bagaimana ia menjadi stressor kepada kebimbangan masyarakat seluruh dunia. Kajian ini diteruskan dengan membincangkan tentang teori REBT dalam kaunseling dan penggunaannya dalam isu-isu kebimbangan yang meluas. Diakhirnya pengkaji mengilustrasikan contoh penggunaan teknik $\mathrm{ABCDE}$ dalam bentuk jadual yang mudah diaplikasikan dalam mengatasi kebimbangan khusus kepada situasi pandemik COVID-19.

\section{Sorotan Literatur}




\section{Impak COVID-19}

Wabak COVID-19 telah mengakibatkan pelbagai kesukaran tehadap kehidupan manusia dari sudut kesihatan, ekonomi, aktiviti sosial, pendidikan dan lain-lain. Ia dianggap stressor yang membimbangkan semua orang kerana mengancam nyawa kita serta individu tersayang. Menurut Choi et.al (2020), respon psikososial kepada penyakit berjangkit yang melanda boleh jadi pelbagai meliputi perasaan bimbang, ada yang berasa risau keterlaluan jika terkena jangkitan, mengambil langkah berjaga-jaga yang terlalu ekstrim dan berlebihan serta timbul permintaan yang tinggi terhadap perkhidmatan hospital dan rawatan dalam tempoh yang singkat.

Dari sudut aktiviti sosial manusia, wabak ini memberi gangguan yang teruk terhadap rutin harian, ada yang terpaksa berpisah dengan keluarga dan rakan-rakan dan rasa terasing daripada masyarakat (Choi et al. 2020). Ada individu yang bekerja jauh daripada keluarga merasa tertekan kerana tidak dapat pulang berjumpa keluarga akibat perintah kuarantin, lockdown, atau kawalan pergerakan. Ini menyebabkan individu mengalami kemurungan dan kebimbangan keran risau bilakah mereka boleh berjumpa semula dengan ahli keluarga masing-masing. Seluruh dunia mengalami interaksi sosial yang cukup terbatas, aktiviti perkumpulan berskala besar tidak dapat dijalankan antaranya majlis keramaian, perkahwinan, aktviti sukan berkumpulan seperti bola sepak dan sebagainya. Dari sudut aktiviti keagamaan bagi semua agama dan juga ibadah contohnya seperti solat berjemaah, solat jumaat bagi orang Islam juga turut terganggu. Terdapat juga masjid-masjid dan surau yang ditutup.

Dari sudut ekonomi, para peniaga, usahawan kecil dan sederhana dalam pelbagai sektor turut terjejas serta mengalami kerugian malah ada premis atau perusahaan yang tepaksa ditutup kerana pembeli atau pelanggan yang semakin berkurangan apabila pihak berkuasa mula memerintahkan untuk melaksanakan Perintah Kawalan Pergerakan. Perintah ini juga memberi kesan besar kepada pekerja-pekerja yang terlibat dalam sektor perhotelan, penerbangan, pelancongan dan lain-lain kerana larangan rentas negeri dan juga adanya perintah sekatan keluar atau masuk negara. Ekonomi negara yang terjejas telah menyebabkan ramai yang diberhentikan kerja. Choi et. al (2020) juga mengatakan ada pekerja yang dipotong gaji implikasi daripada wabak ini. Ketidakpastian ini menyebabkan sebilangan masyarakat risau mengenai masa depan kerjaya masing-masing serta tertekan kerana gagal menyara dan memenuhi keperluan keluarga. Masalah kewangan, kemiskinan yang meruncing sudah pasti memberi tekanan besar dalam kehidupan seseorang. Secara global, majoriti pakar telah memberi amaran bahawa kesan COVID19 terhadap ekonomi, perusahaan perniagaan dan ketiadaan pekerjaan boleh mencalarkan imej kendiri (self esteem) seseorang dan membawa kepada bunuh diri (Chabraa, 2020).

Dari segi pendidikan, sekolah-sekolah terpaksa ditutup. Kanak-kanak, pelajar sekolah mahupun universti tidak dapat meneruskan persekolahan dan pembelajaran seperti biasa akibat keterbatasan interaksi sosial. Dengan fasiliti sedia ada, para guru telah berusaha melaksanakan proses pembalajaran atas talian yang mana terdapat cabaran tersendiri dimana terdapat pelajar yang tiada akses internet yang baik terutamanya bagi pelajar yang tinggal di kawasan pedalaman atau ketiadaan alat teknologi yang bersesuaian di rumah. Selain itu, masalah suasana belajar yang tidak kondusif dan sebagainya telah menyebabkan pembelajaran agak terganggu. Menurut Jarnawi (2020) ibu bapa juga terbeban kerana terpaksa mengambil alih tugas mengajar dan memantau pembelajaran anak dirumah yang mana menuntut mereka menguasai pelbagai matapelajaran. Menurut Irawan. et al. (2020) pula, bebanan tugasan atas talian merupakan faktor penyebab kepada stress pelajar, dimana memerlukan mereka untuk cepat menguasai penggunaan media atas talian walaupun mereka baru sahaja mempelajarinya. Selain itu, keadaan yang memaksa mereka untuk sentiasa berkurung dirumah, tiada aktiviti fizikal dan kurang interaksi dengan rakan sebaya menyebabkan keadaan mereka semakin memburuk. Ini juga boleh memberi kesan psikologi kepada pelajar dalam bentuk ketakutan atau kebimbangan.

\section{Kebimbangan di Musim Pandemik COVID-19}

Kebimbangan adalah sejenis kecelaruan kesihatan mental yang boleh dipicu oleh stress. Kedua-dua stress dan kebimbangan mempunyai simptom yang hampir sama dan agak sukar untuk dikesan perbezaan antara keduanya. Menurut Buheji et al. (2020) simptom seperti kesukaran tidur pada waktu malam, 
keletihan, bimbang yang berlebihan, kurang fokus, kerengsaan disamping simptom fizikal lain seperti kadar denyutan jantung yang laju, ketegangan otot dan sakit kepala merupakan simptom yang ada pada kedua-duanya.

Covid-19 boleh membawa kepada simptom kebimbangan iaitu daripada aspek kognitif, emosi, somatik, autonomik dan juga tingkahlaku dimana ia menunjukkan darjah yang berbeza bergantung mengikut ciri sesuatu populasi yang berisiko. Antara simptom kognitif adalah konsentrasi yang lemah, masalah ingatan, dan rasa tidak boleh dibantu (helpless), manakala simptom emosi pula adalah perasaan takut, gerun, terseksa, cepat marah dan sensitif. Simptom somatik pula meliputi insomnia, sakit badan, hilang selera makan serta kurang nafsu seks. Manakala simptom autonomik pula terdiri daripada jantung yang berdegup laju, berdebar, sentiasa mahu terkencing dan sakit perut. Simptom tingkahlaku bagi kebimbangan pula boleh dilihat melaui tingkahlaku agresif, kejam, dan juga pengelakan terhadap orang ramai, tempat atau situasi (Chhabra, 2020).

Kajian oleh Roy et al. (2020) terhadap 662 orang responden mendapati majoritinya mengalami kebimbangan. Lebih $80 \%$ orang responden terlalu memikirkan tentang COVID-19 sepanjang minggu. $40 \%$ responden pula paranoid memikirkan sepanjang minggu adakah mereka telah terkena jangkitan, $72 \%$ responden melaporkan berasa bimbang terhadap diri sendiri dan keluarga serta $12 \%$ mengalami kesukaran tidur. Kajian Wang et al. (2020) terhadap 1210 orang responden daripada 194 bandar di China mendapati $16.5 \%$ mengalami simptom kemurungan, $28.8 \%$ melaporkan simptom kebimbangan dan $8.1 \%$ mengalami stress daripada sederhana kepada teruk. Kajian ini juga mendapati $75.2 \%$ responden berasa bimbang tentang diri dan ahli keluarga jika berjangkit penyakit ini. Selain itu, kajian ini juga mendapati wanita mengalami lebih tinggi kadar stress, kebimbangan dan kemurungan berbanding jantina lelaki.

Kajian Sundarasen et al., (2020) terhadap 983 orang responden dalam kalangan pelajar di Malaysia mendapati $20.4 \%, 6.6 \%$ dan $2.8 \%$ pelajar mengalami kebimbangan di tahap minima kepada sederhana, sederhana teruk dan sangat teruk semasa pandemik COVID-19. Kesemua faktor umur jantina, bidang atau kos dan kondisi kewangan mempunyai hubungan signifikan dengan tahap kebimbangan. Stressor utama adalah kerana kekangan kewangan, pembelajaran atas talian, ketidakpastian tentang prestasi akademik, graduasi dan juga prospek kerja bagi masa depan. Dapatan ini juga disokong oleh kajian Baloran et al. (2020) yang mendapati majoriti pelajar menunjukkan simptom kebimbangan semasa lockdown dimana sebanyak $62.64 \%$ mengalami kerisauan mengenai sumber makanan dan kewangan, manakala 54\% pelajar mengelakkan kontak sosial dan perjumpaan besar- besaran.

\section{Rational Emotive Behaviour Theraphy (REBT)}

Rational Emotive Behaviour Theraphy (REBT) adalah teknik atau terapi yang digunakan dalam sesi kaunseling yang diasaskan oleh Albert Ellis. Terapi ini juga dikenali sebagai terapi A-B-C. Terapi ini mengandaikan bahawa manusia sebagai penilai, perunding dan pengawal diri. Menurut terapi ini juga, gangguan emosi adalah disebabkan oleh pemikiran yang tidak rasional. Manusia dilahirkan dengan satu potensi untuk berfikiran secara rasional dan tidak rasional. Manusia sendirilah yang menyebabkan dirinya berasa terganggu dan gangguan itu bukanlah disebabkan oleh sumber- sumber luaran tetapi berpunca daripada individu itu sendiri (Dryden \& Bernard, 2019).

Ellis menyatakan bahawa manusia boleh membangkitkan pemikiran, emosi dan tingkahlaku disfungsi. Contoh pemikiran disfungsi ialah obsesi, kecelaruan panic, depresi, kebimbangan, kritikan diri dan membenci diri (Hickey, 2019). Dalam teori ini menyebut seseorang perlu mengubah konsep berfikir yang destruktif kepada konsep berfikir yang rasional supaya dapat menukar atau menambahkan emosi positif yang akhirnya boleh mengubah perilaku memusnah sesorang kepada perilaku yang positif dan membina.

Prinsip asas teori ini yang pertama ialah klien bertanggungjawab keatas emosi dan tindakannya sendiri, kedua, emosi yang mengganggu seseorang klien dan tingkahlaku disfungsi klien adalah produk pemikiran tidak rasionalnya. Yang ketiga seseorang klien boleh mempelajari pandangan yang lebih realistik, dan melalui amalan boleh menjadikannya sebahagian daripada repetoirenya. 
Ellis pada asalnya mengemukakan teori "A-B-C". A ialah pengalaman yang mengaktivasikan salah percaya klien dan menyebabkan $\mathrm{C}$ iaitu konsekuen emosi atau tingkahlaku. B ialah sistem kepercayaan klien, samada rasional atau tidak rasional, iaitu variabel penghalang yang sebenarnya menjadikan $\mathrm{C}$. Kemudian beliau telah menambah D dan E, menjadikan teorinya sekarang ini teori A-B-C-D-E. D adalah penyangkalan pemikiran dan kepercayaan tidak rasional klien dan $\mathrm{E}$ adalah emosi baru atau kesan baru yang lebih rasional (Dryden \& Bernard, 2019).

Terapi REBT ialah satu pendekatan pengajaran yang menolong individu mencapai satu perubahan dalam pemikiran untuk membolehkan mereka mengawal bagaimana mereka mengalami emosi mereka samada sihat atau tidak sihat. Peranan kaunselor atau fasilitator adalah untuk memberi fokus kepada penghapusan respons emosi dan pemikiran tidak rasional dan dengan secara rasional mencabar kepercayaan dan memberikan klien pentaksiran yang lebih realistik dalam usaha mengubah pemikiran, emosi dan tingkahlaku yang disfungsi (Aina, 2015).

Menurut Dryden \& Bernard (2019) Teori REBT di dapati telah digunakan secara meluas dalam sesi kaunseling atau terapi di kalangan klien yang pelbagai antaranya warga tua, kanak-kanak, pelajar, golongan OKU, LGBT dan sebagainya. Terapi ini juga didapati boleh membantu klien dengan isu kebimbangan dan keresahan. Kajian yang dilakukan oleh Mutiah (2019) mendapati REBT mampu mengurangkan kebimbangan pelajar terhadap subjek Matematik dengan menyangkal pemikiran tidak rasional mereka bahawa matematik sukar difahami dan rumit. Pelaksanaan REBT telah dilaksanakan dalam bentuk kaunseling kelompok sebanyak lima sesi. Kajian Turner \& Barker (2013) juga mendapati REBT mampu mengatasi kebimbangan dikalangan atlet sukan kriket dimana pemikiran tidak rasional telah mengakibatkan kebimbangan dan menyebabkan pretasi mereka menurun, menyebabkan ada yang menarik diri, mengalami burn out dan masalah emosi negatif yang lain. Kajian ini juga turut disokong oleh dapatan kajian Wood \& Woodcock (2017) yang membuat kajian kes penggunaan REBT keatas atlet muda dalam sukan tenis.

\section{Metod Kajian}

Kajian ini merupakan kajian kualitatif yang menganalisis dokumen daripada sumber buku dan artikelartikel dalam jurnal yang mengkaji kesan COVID-19 terhadap kebimbangan serta penggunaan Teori REBT dalam mengatasi kebimbangan.

\section{Perbincangan dan Hasil Kajian}

\section{Aplikasi REBT dalam Menangani Kebimbangan Semasa Pandemik COVID-19}

Covid 19 telah melahirkan pelbagai pemikiran- pemikiran yang membimbangkan antaranya bimbang djangkiti, bimbang akan kematian, stigma masyarakat kepada pesakit yang dijangkiti atau kontak rapat mereka, bimbang tidak dapat menjaga orang tersayang, tidak dapat menyara keluarga serta kebimbangan akan duit tidak mencukupi. Menurut Chabraa (2020) wabak ini menghasilkan kebimbangan kerana ia dipenuhi dengan pelbagai ketidakpastian. Oleh itu automatiknya manusia dipenuhi dengan pemikiran negatif yang membawa kepada pengherotan kognitif. Perlu ditekankan ke dalam pemikiran klien bahawa apa yang mereka hargai dan rasai adalah penting dan mereka berkuasa untuk mencapainya. Bertindak mengikut nilai klien boleh membantu meningkatkan efikasi kendiri klien dan membantu mereka merasa lebih baik tentang diri sendiri serta memberi mereka perasaan bahawa mereka mampu mengawal kehidupan mereka walaupun mereka tidak mepunyai kawalan sepenuhnya untuk mengawal virus tersebut atau apa yang akan terjadi kepada mereka.

Menurut Hickey (2019) apabila bekerja dengan individu yang mengalami kebimbangan, konseptualisasi kebimbangan sebagai emosi negatif adalah penting untuk membantu perubahan klien. REBT ialah teori yang menekankan kepentingan mengubah emosi negatif yang tidak sihat kepada emosi yang sihat dimana 
ia boleh membantu kepada pencapaian matlamat, bukan semata-mata cuba mengurangkan kebimbangan klien tersebut.

Justeru itu pengkaji merangka jadual aplikasi teknik ABCDE dalam REBT dengan mengandaikan contoh pemikiran tidak sihat iaitu B (beliefs) klien yang mungkin wujud berdasarkan A iaitu krisis (activating event) COVID -19 yang melanda kini sehingga ia mengakibatkan $\mathrm{C}$ iaitu kesan kepada pemikiran dan tingkhlaku yang melahirkan kebimbangan (consequence feeling and behaviour) berdasarkan kajiankajian lepas yang dibincangkan di atas.

Jadual 1: Aplikasi Teknik ABCDE dalam REBT semasa pandemik COVID-19

\begin{tabular}{|c|c|c|c|c|}
\hline $\begin{array}{l}\text { Krisis } \\
\text { (Activating } \\
\text { event) }\end{array}$ & $\begin{array}{l}\text { Pemikiran } \\
\text { (Beliefs) }\end{array}$ & $\begin{array}{l}\text { Kesan kepada } \\
\text { pemikiran dan } \\
\text { tingkahlaku } \\
\text { (Consequence } \\
\text { Feeling And } \\
\text { Behaviour) }\end{array}$ & $\begin{array}{l}\text { Pertikaikan pemikiran } \\
\text { dan emosi yang negatif } \\
\text { (Disputes the Beliefs) }\end{array}$ & $\begin{array}{l}\text { Emosi dan } \\
\text { pemikiran } \\
\text { yang baru dan } \\
\text { berkesan } \\
\text { (Effective New } \\
\text { Beliefs And } \\
\text { Consequences) }\end{array}$ \\
\hline \multirow[t]{3}{*}{ COVID-19 } & $\begin{array}{l}\text { Adakah saya } \\
\text { dan keluarga } \\
\text { akan selamat? }\end{array}$ & $\begin{array}{l}\text {-Risau, cemas dan } \\
\text { tidak mahu keluar ke } \\
\text { mana mana. } \\
\text {-Tidak proaktif }\end{array}$ & $\begin{array}{l}\text { Selagi saya } \\
\text { mengamalkan SOP } \\
\text { yang telah dianjurkan } \\
\text { KKM, InsyaAllah saya } \\
\text { selamat }\end{array}$ & $\begin{array}{l}\text { Keluar bekerja } \\
\text { dengan rasa } \\
\text { tenang, anak- } \\
\text { anak dihantar } \\
\text { ke sekolah }\end{array}$ \\
\hline & $\begin{array}{l}\text { Adakah saya } \\
\text { akan kehilangan } \\
\text { kerja? }\end{array}$ & $\begin{array}{l}\text {-Bekerja dalam } \\
\text { tekanan dan sentiasa } \\
\text { bimbang. } \\
\text {-Prestasi kerja } \\
\text { menurun }\end{array}$ & $\begin{array}{l}\text { Selagi saya bekerja } \\
\text { bersungguh-sungguh, } \\
\text { saya tidak akan } \\
\text { dibuang kerja }\end{array}$ & $\begin{array}{l}\text { Bekerja dalam } \\
\text { keadaan tenang } \\
\text { tanpa } \\
\text { kerisauan }\end{array}$ \\
\hline & $\begin{array}{l}\text { Adakah } \\
\text { COVID-19 ini } \\
\text { akan berterusan } \\
\text { selamanya dan } \\
\text { duit tidak } \\
\text { mencukupi } \\
\text { untuk kami } \\
\text { sekeluarga? }\end{array}$ & $\begin{array}{l}\text {-Stress, bimbang, } \\
\text { sukar tidur } \\
\text {-Bergaduh dengan } \\
\text { isteri dan memarahi } \\
\text { anak-anak }\end{array}$ & $\begin{array}{l}\text { Walaupun COVID-19 } \\
\text { masih ada tetapi saya } \\
\text { masih punya kudrat } \\
\text { untuk bekerja mencari } \\
\text { nafkah, selagi saya } \\
\text { rajin bekerja, duit kami } \\
\text { pasti mencukupi }\end{array}$ & $\begin{array}{l}\text { Tinggal } \\
\text { dengan } \\
\text { keluarga dalam } \\
\text { keadaan tenang } \\
\text { dan melayan } \\
\text { keluarga } \\
\text { dengan baik. }\end{array}$ \\
\hline
\end{tabular}

Dalam menggunakan terapi ini kaunselor perlu bersama- sama klien berdiskusi dan mengenal pasti apakah pemikiran negatif atau tidak rasional yang mengganggu klien seterusnya membincangkan bagaimana pemikiran -pemikiran ini mempengaruhi emosi seterusnya tingkahlaku mereka. Fasilitator atau kaunselor perlu membantu klien untuk memahami emosi dan perlakuan mereka yang berpunca daripada kepercayaan dan pemikiran yang tidak rasional. Justeru itu format rantai masalah A-B-C boleh digunakan bagi membantu klien. Jadi klien perlu ditunjukkan hubungan antara B dengan A dan hubungan antara B dengan $\mathrm{C}$, serta hubungan tak langsung antara A dengan $\mathrm{C}$ yang berpunca daripada B. Klien juga perlu didedahkan bahawa sistem kepercayaan atau pemikiran negatif sedia ada perlu dihujah dan dicabar agar dapat digantikan dengan pilihan lain, iaitu membentuk sistem kepercayaan baru yang lebih terbuka dan realistik. Proses ini memerlukan usaha kolaboratif antara klien dan kaunselor yang bersifat terbuka dalam menerima pandangan satu sama lain. Setelah D iaitu pemikiran dan emosi ini dipertikaikan dan diganti, seterusnya boleh dibincangkan pula $\mathrm{E}$ iaitu bagaimana perubahan pemikiran ini boleh membawa kepada emosi baru yang lebih sihat, produktif dan bahagia pada musim COVID-19. Diingatkan proses menyangkal pemikiran klien memerlukan tahap kognitif atau kreativiti yang agak tinggi bagi kaunselor dan juga penerimaan kognitif klien. Apa yang boleh disangkal adalah, masyarakat seluruh dunia sedang mengalami pandemik ini, dan yang menjadi persoalan, bagaimana sesetengah orang masih kekal produktif, bersemangat, waras dan sihat tanpa mengalami kebimbangan yang destruktif. Perasaan bimbang itu normal namun, kebimbangan yang melampau boleh mengakibatkan keadaan bertabah buruk pada musim pandemik ini. 


\section{Kesimpulan}

Secara kesimpulannya, pandemik COVID-19 sememangnya memberi tekanan kepada semua pihak dan mampu mengakibatkan kebimbangan kepada kita, malahan, sehingga ke hari ini angka jangkitan dan kematian semakin bertambah di seluruh dunia. Oleh itu, semua pihak perlu bersama-sama cakna dan berganding bahu dalam menangani isu kesihatan mental yang semakin memburuk ini disamping menjaga kesihatan fizikal daripada dijangkiti wabak ini. Kajian yang dilakukan ini telah membincangkan salah satu kaedah terapi yang diharapkan dapat membantu mengatasi isu kebimbangan semasa COVID-19 dengan mengilustrasikan praktikaliti langkah-langkah ABCDE dalam teori REBT secara ringkas supaya ia boleh digunakan oleh orang awam, atau sebagai bantuan psikologi awal oleh fasilitator, sukarelawan, kaunselor mahupun petugas perubatan terhadap pesakit. Kajian ini boleh dikembangkan lagi dengan membincangkan penggunaannya secara meluas bagi klien atau pesakit yang mengalami isu kesihatan mental lain pada musim pandemik seperti kemurungan dan lain-lain. Selain itu, kajian ini juga boleh dihuraikan lagi secara terperinci menggunakan teknik-teknik lain yang ada dalam teori REBT dengan melibatkan demografi klien yang pelbagai.

\section{Rujukan}

Aina Razlin, M. R. (2015). Kenali REBT semudah ABC: Teori \& Konsep Asas Terapi Rasional Emotif Tingkah Laku. Universiti Malaysia Sarawak.

Baloran, E. T. (2020). Knowledge, Attitudes, Anxiety, and Coping Strategies of Students during COVID-19 Pandemic. Journal of Loss and Trauma, 25(8), 635-642.

Çalık, M. (2020). Determining The Anxiety And Anxiety Levels Of University Students In The COVID 19 Outbreak. International Journal of Medical Science and Clinical Invention, 7(07),

Chhabra, S. (2020). Psychological Implications of COVID-19 Pandemic - A Wide Spectrum of Manifestations. Journal of Evolution of Medical and Dental Sciences, 9(33), 2386-2391.

Choi, E. P. H., Hui, B. P. H., \& Wan, E. Y. F. (2020). Depression and anxiety in Hong Kong during COVID-19. International Journal of Environmental Research and Public Health, 17(10).

Dryden, W., \& Bernard, M. E. (2019). REBT with diverse client problems and populations. REBT with Diverse Client Problems and Populations. Springer International Publishing.

Hickey, M. (2019). REBT and anxiety disorders. REBT with Diverse Client Problems and Populations.

Irawan. A.W., Dwisona, L. (2020). Psychological Impacts of Students on Online Learning During the Pandemic COVID-19. KONSELI: Jurnal Bimbingan Dan Konseling (E-Journal), 7(1), 53-60.

Jarnawi, J. (2020). Mengelola Cemas di Tengan Pandemik Corona. Jurnal Al Taujih: Bimbingan Dan Konseling Islam, 3(1), 60-73.

Mutiah, R. (2019). Gambaran Pelaksanaan Konseling Kelompok dengan Teknik REBT dalam upaya mengatasi kecemasan Matematika Siswa SMP, 4(1), 37-44.

Roy, D., Tripathy, S., Kar, S. K., Sharma, N., Verma, S. K., \& Kaushal, V. (2020). Study of knowledge, attitude, anxiety \& perceived mental healthcare need in Indian population during COVID-19 pandemic. Asian Journal of Psychiatry, 51(51), 1-7.

Sundarasen, S., Chinna, K., Kamaludin, K., Nurunnabi, M., Baloch, G. M., Khoshaim, H. B., Sukayt, A. (2020). Psychological impact of covid-19 and lockdown among university students in malaysia: Implications and policy recommendations. International Journal of Environmental Research and Public Health, 17(17), 1-13.

Turner, M., \& Barker, J. B. (2013). Examining the Efficacy of Rational-Emotive Behavior Therapy (REBT) on Irrational Beliefs and Anxiety in Elite Youth Cricketers. Journal of Applied Sport Psychology, 25(1), 131-147.

Wang, C. Riyu Pan, R., Wan X., Tan, Y. (2020). Mental health in the COVID-19 pandemic. QJM: Monthly Journal of the Association of Physicians, 113(5), 311-312.

Wood, A., \& Woodcock, C. (2017). "Is it really that bad?": A case study applying Rational Emotive Behavior Therapy (REBT) with an elite youth tennis player. Rational Emotive Behavior Therapy in Sport and Exercise, (November), 206-218. 